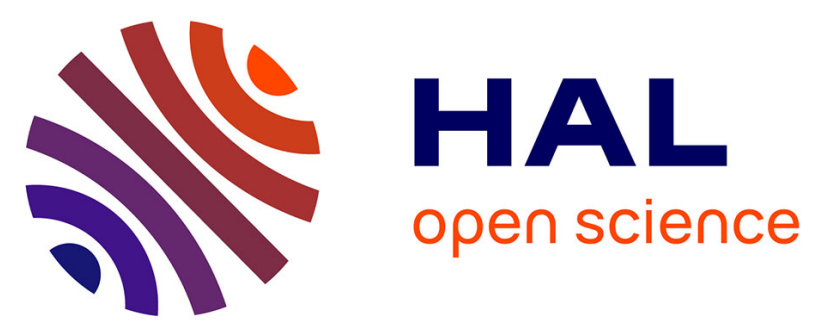

\title{
Chevalierinoside B and C: Two new isoflavonoid glycosides from the stem bark of Antidesma laciniatum Muell. Arg (syn. Antidesma chevalieri Beille)
}

Marie Geneviève Djouossi, Florence Déclaire Mabou, Perrin Lanversin Foning Tebou, David Ngnokam, Leon Tapondjou, Dominique Harakat, Laurence Voutquenne-Nazabadioko

\section{To cite this version:}

Marie Geneviève Djouossi, Florence Déclaire Mabou, Perrin Lanversin Foning Tebou, David Ngnokam, Leon Tapondjou, et al.. Chevalierinoside B and C: Two new isoflavonoid glycosides from the stem bark of Antidesma laciniatum Muell. Arg (syn. Antidesma chevalieri Beille). Phytochemistry Letters, 2014, 9, pp.149-152. 10.1016/j.phytol.2014.05.013 . hal-01996590

\section{HAL Id: hal-01996590 \\ https://hal.univ-reims.fr/hal-01996590}

Submitted on 8 Nov 2021

HAL is a multi-disciplinary open access archive for the deposit and dissemination of scientific research documents, whether they are published or not. The documents may come from teaching and research institutions in France or abroad, or from public or private research centers.
L'archive ouverte pluridisciplinaire HAL, est destinée au dépôt et à la diffusion de documents scientifiques de niveau recherche, publiés ou non, émanant des établissements d'enseignement et de recherche français ou étrangers, des laboratoires publics ou privés. 
Chevalierinoside B and C: Two new isoflavonoid glycosides from the stem bark of Antidesma laciniatum Muell. Arg (syn. Antidesma chevalieri Beille)

Marie Geneviève DJOUOSSI ${ }^{a}$, Florence Déclaire MABOU ${ }^{a}$, Perrin Lanversin FONING TEBOU ${ }^{a}$, David NGNOKAM ${ }^{a^{*}}$, Leon A. TAPONDJOU ${ }^{a}$, Dominique HARAKAT ${ }^{\mathrm{b}}$ and Laurence VOUTQUENNE-NAZABADIOKO ${ }^{c}$

${ }^{a}$ Faculty of Science, Department of Chemistry, University of Dschang, P.O. Box 67. Dschang Cameroon

bService Commun d'Analyses, Institut de Chimie Moléculaire de Reims (ICMR), CNRS UMR 7312, Bat. 18 B.P.1039, 51687 Reims Cedex2, France

${ }^{\mathrm{c}}$ Groupe Isolement et Structure, Institut de Chimie Moléculaire de Reims (ICMR), CNRS UMR 7312, Bat. 18 B.P.1039, 51687 Reims Cedex2, France

${ }^{*}$ Corresponding author. Tel. (237)96932925. E-mail. dngnokam@yahoo.fr 


\section{Highlights}

- Two news isoflavonoids were isolated from Antidesma laciniatum (syn. A. chevalieri).

- The structure was characterized by extensive 2D-NMR studies.

- Seven known compounds were also isolated from this plant. 


\section{ABSTRACT}

Chevalierinosides B (1) and C (2), two new isoflavonoid glycosides, characterized as biochanin A 7O-[ $\beta$-d-apiofuranosyl-( $1 \rightarrow 2)-\beta$-d-glucopyranoside $]$ and genistein $7-\mathrm{O}-[\beta$-d-apiofuranosyl-( $1 \rightarrow 2)-\beta$ d-glucopyranoside], together with the known isoflavonoids, chevalierinoside A (3) and genistein 7O- $\beta$-d-glucopyranoside (4), kaempferol 3-O- $\beta$-d-glucopyranoside (5) and triterpenes, friedelin (6), betulinic acid (7), 30-oxobetulinic acid (8), 30-hydroxybetulinic acid (9), were isolated from the stem bark of Antidesma laciniatum Muell. Arg. (syn. Antidesma chevalieri Beille). Their structures were established by direct interpretation of their spectral data, mainly HR-TOFESIMS, $1 \mathrm{D}-\mathrm{NMR}\left({ }^{1} \mathrm{H},{ }^{13} \mathrm{C}\right.$ and DEPT) and 2D-NMR (COSY, NOESY, TOCSY, HSQC and HMBC), and by comparison with the literature.

Keywords: Antidesma laciniatum/Antidesma chevalieri, Phyllantaceae, isoflavonoid glycosides, chevalierinosides, triterpene, structure elucidation 


\section{INTRODUCTION}

Isoflavonoids represent a group of secondary metabolites widely distributed in higher plants. They often occurred in plants as glycosides in which one or more of the phenolic hydroxyl groups or aromatic carbons are combined with sugar residues (Mackova et al., 2006, Veitch, 2007, Botta et al., 2009, Yao-Kouassi et al., 2008, Farag et al., 2001, Wang et al., 2006 and Tang et al., 2008). Isoflavonoids have attracted considerable interest because of a large variety of biological activities, such as antioxidant (Komiyama et al., 1989 and Harper et al., 1999), antiplasmodial (Yenesew et al., 2003 and Kraft et al., 2000), cytotoxic (Cottiglia et al., 2005 and Nkengfack et al., 2001), antiinflammatory (Laupattarakasem et al., 2004 and $\underline{\text { Rahman et al., 2003) and antimicrobial (Sato et al., }}$ 2003 and Redko et al., 2007). Recently, we reported the isolation of one new isoflavonoid glycoside named chevalierinoside A (Djouossi et al., 2014), from the stem bark of a small tree, Antidesma laciniatum Muell. Arg. (syn. Antidesma chevalieri Beille), used in Africa to prevent miscarriage and to treat intestinal complaints ( $\underline{\text { Schmelzer, 2008) }}$. During phytochemical investigation of the methanol extract of the stem bark of this small tree (Phyllantaceae), we found some minor compounds that were difficult to separate due to the small quantity of the extract. As an extension of our previous work, we now report the isolation of two new isoflavonoid glycosides, chevalierinosides B (1) and C (2), together with the known chevalierinoside A (3), genistein 7-O- $\beta$-d-glucopyranoside (4), kaempferol 3-O- $\beta$-d-glucopyranoside (5), friedelin (6), betulinic acid (7), 30-oxobetulinic acid (8), 30hydroxybetulinic acid (9), from the methanol extract of the stem bark of the same highest and oldest species, founded in the same Region during another fieldtrip collection.

\section{Results and discussion}

Compound 1 was obtained as a yellowish gum. Its molecular formula $\mathrm{C}_{27} \mathrm{H}_{30} \mathrm{O}_{14}$ was determined on the basis of its HR-TOFESIMS spectrum exhibiting a pseudo-molecular ion peak at $\mathrm{m} / \mathrm{z} 601.1537$ $[\mathrm{M}+\mathrm{Na}]^{+}$(calcd. 601.1533) and confirmed by ${ }^{13} \mathrm{C}$ NMR and DEPT analysis. This was in accord with an isoflavone having one hydroxyl, one methoxyl, and one pentosyl-hexosyl substitutions. The IR

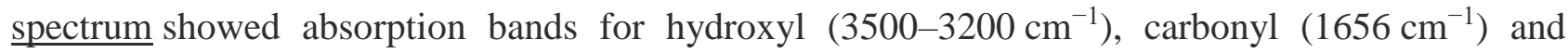
aromatic (1614 and $1581 \mathrm{~cm}^{-1}$ ) functionalities. The NMR spectral data for the aglycon moiety were in agreement with those of 5,7-dihydroxy-4'-methoxyisoflavone (biochanin A) (Santos et al., 1995). The ${ }^{1} \mathrm{H}$ NMR spectrum of 1 exhibited signals at $\delta 8.20(\mathrm{H}-2, s), 6.71(\mathrm{H}-8, d, J=2.3 \mathrm{~Hz}), 6.52(\mathrm{H}-$ $6, d, J=2.3 \mathrm{~Hz}), 7.52\left(\mathrm{H}-2^{\prime} / \mathrm{H}-6^{\prime}, d, J=8.9 \mathrm{~Hz}\right)$ and $7.02\left(\mathrm{H}-3^{\prime} / \mathrm{H}-5^{\prime}, d, J=8.9 \mathrm{~Hz}\right)$ indicative of substitutions on carbons 5,7 and $4^{\prime}$ of the isoflavone. The signal at $\delta 3.86(s)$ correlated to the ${ }^{13} \mathrm{C}$ NMR signal at $\delta 159.7$ in the HMBC spectrum (Table 1), confirming that the methoxyl group was 
located at C-4' in biochanin A as observed with chevalierinoside A (3) (Djouossi et al., 2014) and lanceolarin ( $\underline{\text { Rao et al., 1989) }}$ ) and not at C-5 as in eriosemaside C (Ma et al., 1999). After acid hydrolysis of $\mathbf{1}$, only two sugar units, glucose and apiose were detected by TLC while the aglycon was also identified to biochanin A as previously described (Djouossi et al., 2014, Santos et al., 1995). The difference between chevalierinoside A (3) and $\mathbf{1}$ was the absence of the rhamnosyl moiety in $\mathbf{1}$. This was supported by the ${ }^{1} \mathrm{H}$ NMR spectrum of $\mathbf{1}$ which displayed only two sugar anomeric protons at $\delta 5.16(d, J=7.5 \mathrm{~Hz})$ and $5.48(d, J=1.7 \mathrm{~Hz})$ giving correlations with two anomeric carbon at $\delta 98.8$ and 109.5 respectively in the HSQC spectrum (Table 1). The chemical shift of the terminal oxymethylene carbon $(\mathrm{C}-6 ; \delta 61.0)$ of the glucopyranosyl moiety also confirmed the absence of substitution at this position (Djouossi et al., 2014). Complete assignments of each sugar proton system were achieved by analysis of ${ }^{1} \mathrm{H}-{ }^{1} \mathrm{H}$ COSY, TOCSY and NOESY spectra while carbons were assigned from HSQC and HMBC spectra. Evaluation of the spin-spin couplings and chemical shifts allowed the identification of one terminal $\beta$-apiofuranosyl (Api) and one inner $\beta$-glucopyranosyl (Glc) units. The D-configuration for glucose and apiose was suggested by comparison of the NMR $\underline{\text { data }}$ of 1 with those of chevalierinoside A (3) (Djouossi et al., 2014), and, was confirmed by GC$\underline{\mathrm{MS}}$ after derivatization.

The HMBC spectrum correlations between H-1 ( $\delta 5.16)$ of Glc and C-7 ( $\delta$ 163.3) of the aglycon indicated that Glc was linked at C-7 of the aglycon. Furthermore, the HMBC correlation between H-1 $(\delta 5.48)$ of Api and C-2 ( $\delta 77.3)$ of Glc established the connectivity between Api and Glc. This was supported in comparison between ${ }^{13} \mathrm{C}$ data of $\mathbf{1}$ with those of eriosemaside $\mathrm{C}$ (Ma et al., 1999) possessing the same glycosidic linkage and lanceolarin (Rao et al., 1989) possessing the apiose unit linked in position 6 of the glucose unit. Therefore, the oligosaccharide at C-7 of the aglycon was established as $O$-[ $\beta$-D-apiofuranosyl-( $1 \rightarrow 2)-\beta$-D-glucopyranoside]. On the basis of the above evidences, the structure of compound 1 was determined as biochanin A 7- $O$-[ $\beta$-D-apiofuranosyl$(1 \rightarrow 2)-\beta$-D-glucopyranoside], a new isoflavonoid glycoside named chevalierinoside B.

Compound 2, a yellowish gum, had a pseudo-molecular ion peak at $\mathrm{m} / z 587.1379[\mathrm{M}+\mathrm{Na}]^{+}$(calcd. for $\mathrm{C}_{26} \mathrm{H}_{28} \mathrm{O}_{14} \mathrm{Na}$, 587.1377) in the HR-TOFESIMS, one methyl fewer than compound $\mathbf{1}$.

Comparison of their NMR spectroscopic data revealed that $\mathbf{2}$ differed only in ring B of the aglycon moiety. The shielding of C-4' $(\delta 157.5)$ and $\mathrm{H}-3^{\prime} / \mathrm{H}^{\prime} 5^{\prime}(\delta 6.88)$, and the deshielding of $\mathrm{C}-3^{\prime} / \mathrm{C}-5^{\prime}$ ( $\delta$ 114.9) indicated the absence of methyl on the hydroxyl at C-4' (Table 1). These NMR spectral data were in agreement with those of 5,7,4'-trihydroxyisoflavone (genistein) (Chaturvedula and Prakash, 2013). Acid hydrolysis of $\mathbf{2}$ also afforded apiose and glucose, detected by TLC, analysis of 1D- and 2D-NMR spectral data of 2 permitted the identification of one terminal $\beta$-apiofuranosyl (Api) and one inner $\beta$-glucopyranosyl (Glc) units, as in 1. The D-configuration for glucose and 
apiose was determined by GC-MS after derivatization. The HMBC correlation between $\mathrm{H}-1$ $(\delta 5.16)$ of Glc and C-7 ( $\delta$ 163.2) of the aglycon and H-1 $(\delta 5.47)$ of Api and C-2 $(\delta 77.3)$ of Glc, confirmed the same diglycloside moity as in $\mathbf{1}$. Thus, compound $\mathbf{2}$ was established as genistein 7-O[ $\beta$-D-apiofuranosyl-( $1 \rightarrow 2)-\beta$-D-glucopyranoside], named chevalierinoside $\mathrm{C}$.

Structures of known compounds were determined as two isoflavonoids, one flavonoid and four triterpenes by means of Co-TLC, and by comparative analysis of their physical and spectral data with those reported in the literature for chevalierinoside A (3) (Djouossi et al., 2014), genistein 7-O- $\beta$-D-glucopyranoside (4) (Fedoreyev et al., 2008), kaempferol 3-O- $\beta$-D-glucopyranoside (5) (Shahat et al., 2005), friedelin (6) (Chandler and Hooper, 1979), betulinic acid (7) (Sholichin et al., 1980), 30-oxobetulinic acid (8) (Macias et al., 1998) and 30-hydroxybetulinic acid (9) (Mayer, 1996) (Fig. 1).

\section{Experimental}

\subsection{General experimental procedures}

Optical rotations were measured on a Perkin-Elmer 341 polarimeter. ${ }^{1} \mathrm{H}$ and ${ }^{13} \mathrm{C}$ NMR spectra were recorded on a Bruker Avance III 600 spectrometer equipped with a cryoplatform $\left({ }^{1} \mathrm{H}\right.$ at $600 \mathrm{MHz}$ and ${ }^{13} \mathrm{C}$ at $\left.150 \mathrm{MHz}\right)$. 2D-NMR experiments were performed using standard Bruker microprograms (Xwin-NMR version 2.1 software). Chemical shifts $(\delta)$ are reported in parts per million (ppm) with the solvent signals as reference relative to TMS $(\delta=0)$ as internal standard, while the coupling constants ( $J$ values) are given in Hertz $(\mathrm{Hz})$. The IR spectra were recorded with a Shimadzu FT-IR$8400 S$ spectrophotometer. UV spectra were determined as methanol solution with a Cary 50 UV/VIS Spectrophotometer. HR-TOFESIMS experiments were performed using a Micromass QTOF micro instrument (Manchester, UK) with an electrospray source. The samples were introduced by direct infusion in a solution of $\mathrm{MeOH}$ at a rate of $5 \mu \mathrm{L} \mathrm{\textrm {min } ^ { - 1 }}$. $\underline{\mathrm{GC}}-\mathrm{MS}$ experiments were carried out on an MD 800 instrument. Column chromatography (CC) was performed on silica gel 60 (70230 mesh, Merck) and gel permeation on Sephadex LH-20 while TLC was carried out on silica gel $\mathrm{GF}_{254}$ pre-coated plates with detection accomplished by spraying with $50 \% \mathrm{H}_{2} \mathrm{SO}_{4}$ followed by heating at $100{ }^{\circ} \mathrm{C}$, or by visualizing with an UV lamp at 254 and $365 \mathrm{~nm}$.

\subsection{Plant material}

The stem bark of Antidesma laciniatum Muell. Arg. (syn. Antidesma chevalieri Beille) was collected at Bansoa, Menoua Division, West Region of Cameroon, in January 2013. Authentication was done by Mr Victor Nana, a botanist of the Cameroon National Herbarium, Yaoundé, where the voucher specimen (No. 9667/SRF/Cam) is deposited. 


\subsection{Extraction and isolation}

The dried and powdered plant material $(7 \mathrm{~kg})$ was extracted by percolation with methanol $(3 \times 15 \mathrm{~L}$, $72 \mathrm{~h}$ ) at room temperature affording $120 \mathrm{~g}$ of crude extract after evaporation of the solvent under vacuum.

A portion (90 g) of this extract was subjected to silica gel column chromatography (CC) eluting with gradient mixtures of $n$-hexane-EtOAc (1:0, 9:1, 4:1, 7:3, 1:1, 3:7 and 0:1) followed by EtOAc$\mathrm{MeOH}(19: 1,9: 1,17: 3,4: 1,1: 1$ and 0:1). 57 fractions, each $300 \mathrm{~mL}$, were collected and combined on the basis of their TLC profiles to give five fractions noted F1 to F5. Fraction F1 was purified on silica gel CC eluted with $n$-hexane-EtOAc (19:1 and 9:1) and 32 fractions (25 mL each) were collected. Re-crystallization of fractions [12-24] gave friedelin (6) (34.5 mg). Fraction F2 was purified on silica gel CC eluted with $n$-hexane-EtOAc (4:1, 3:2 and 1:1) and 33 sub-fractions (25 mL each) were collected. Re-crystallization of fractions [5-11], [16-20] and [25-29] afford betulinic acid (7) (52 mg), 30-oxobetulinic acid (8) (12 mg) and 30-hydroxybetulinic acid (9) (10.5 mg), respectively. Fractions F3 and F4 were respectively passed through sephadex LH-20 CC eluted with methanol. 42 fractions of $10 \mathrm{~mL}$ each were collected from F3 and 37 others from F4. Fractions [23-40] from F3 (3 g) and [10-25] from F4 (2.5 g) were combined and passed through silica gel CC eluted with EtOAc-MeOH (1:0, 19:1 and 9:1). 46 fractions (50 mL each), were collected and combined on the basis of their TLC profiles. The fractions [1-13] (1.2 g), [14-21] (0.7 g) and [22-46] (1.3 g) were purified separately through sephadex LH-20, eluted with methanol, yielding genistein 7-O- $\beta$-D-glucopyranoside (4) (12 mg) and kaempferol 3-O- $\beta$-D-glucopyranoside (5) (6 mg) from [1-13], compounds 1 (15 mg) and 2 (17 mg) from [14-21], and chevalierinoside A (3) (29 mg) from [22-46]. Attempts of purification of fraction F5 failed.

\subsection{New compounds information}

Chevalierinoside B (1): yellowish gum; $[\alpha]_{\mathrm{D}}^{23}-49.5(c=3.3, \mathrm{MeOH}) ; \mathrm{IR}(\mathrm{NaCl}) v_{\max }\left(\mathrm{cm}^{-1}\right)$ : 3500-3200 (OH); 2925; 1656 (C__ O), 1614, 1581 (aromatic); 1440; 1290; 1249; 1180; 1068; ${ }^{1} \mathrm{H}$ and ${ }^{13} \mathrm{C}$ NMR data, see Table 1; HR-TOFESIMS $m / z: 601.1537[\mathrm{M}+\mathrm{Na}]^{+}$(calcd. for $\mathrm{C}_{27} \mathrm{H}_{30} \mathrm{O}_{14} \mathrm{Na}$, 601.1533).

Chevalierinoside C (2): yellowish gum; $[\alpha]_{\mathrm{D}}^{23}-36.0(c=0.50, \mathrm{MeOH}) ; \mathrm{IR}(\mathrm{NaCl}) v_{\max }\left(\mathrm{cm}^{-1}\right)$ : 3500-3200 (OH); 2920; 1656 (C_O ), 1612, 1575 (aromatic); 1251; 1180; 1072; ${ }^{1} \mathrm{H}$ and ${ }^{13} \mathrm{C}$ NMR data, see Table 1; HR-TOFESIMS m/z: $587.1379[\mathrm{M}+\mathrm{Na}]^{+}$(calcd. for $\mathrm{C}_{26} \mathrm{H}_{28} \mathrm{O}_{14} \mathrm{Na}, 587.1377$ ). 


\subsection{Acid hydrolysis and GC-MS analysis of 1 and 2}

Each of compound $\mathbf{1}(10 \mathrm{mg})$ and $\mathbf{2}(10 \mathrm{mg})$ was respectively dissolved in $\mathrm{MeOH}-2 \mathrm{~N} \mathrm{HCl}(1: 4)$

$(10 \mathrm{~mL})$ and refluxed at $80{ }^{\circ} \mathrm{C}$ for $3 \mathrm{~h}$. After removal of $\mathrm{MeOH}$ under reduced pressure, the aqueous layer was extracted with $\mathrm{CH}_{2} \mathrm{Cl}_{2}(3 \times 5 \mathrm{~mL})$. The combined $\mathrm{CH}_{2} \mathrm{Cl}_{2}$ extracts were washed with $\mathrm{H}_{2} \mathrm{O}$ and evaporated to dryness to afford biochanin A $(1.5 \mathrm{mg})$ (Santos et al., 1995) from 1, and genistein (2 mg) (Chaturvedula and Prakash, 2013) from 2. Each aqueous layer was neutralized by dilute $\mathrm{NaOH}$. The sugar components were analyzed by co-TLC with the mixture $\mathrm{CHCl}_{3} / \mathrm{MeOH} / \mathrm{H}_{2} \mathrm{O}$ (70:30:2). After spraying, apiose gave a weak yellow spot at Rf 0.79, and glucose gave a blue spot at $\operatorname{Rf} 0.71$.

Each previous aqueous layer was concentrated to dryness. The residue obtained was dissolved in pyridine $(1 \mathrm{~mL})$, then $\left(\mathrm{CH}_{3}\right)_{3} \mathrm{SiNHSi}\left(\mathrm{CH}_{3}\right)_{3}(1 \mathrm{~mL})$ was added. After $10 \mathrm{~min}$ at room temperature, the solution was blown to dryness with a stream of nitrogen. The residue was dissolved in diethyl ether then subjected to GC-MS analysis.

Trimethylsilyl ether derivatives were separated using an HP Ac-5 capillary column $(0.25$ x $30 \mathrm{~m})$. Nitrogen was used as the carrier gas. The initial column oven temperature was $180^{\circ} \mathrm{C}$, then increased at $5^{\circ} \mathrm{C} \mathrm{min}{ }^{-1}$ to a final value of $240^{\circ} \mathrm{C}$. The sugars were determined by comparison of retention times $\left(t_{R}\right)$ with standard sugars: $t_{R}(\min )$ Glc 6.86, Api 2.78 .

\section{Acknowledgments}

The authors thank the Région Champagne-Ardenne' and the Département de la Marne' for financial support. The EU-programme FEDER to the PIANET CPER project is also gratefully acknowledged.

\section{References}

Botta B., Menendez P., Zappia G., de Lima R.A., Torge R., Monachea G.D., 2009. Prenylated isoflavonoids: Botanical distribution, structures, biological activities and biotechnological studies. An update (1995-2006). Curr. Med. Chem. 16, 3414-3468.

Chandler R.F., Hooper S.N., 1979. Friedelin and associated triterpenoids. Phytochemistry 18, 711724.

Chaturvedula, V.S.P., Prakash, I., 2013. Isolation and structure elucidation of daizein and genistein from Siraitia grosvenorii. Asian J. Pharm. Res. Dev. 1, 67-72. 
Cottiglia F., Casu L., Bonsignore L., Casu M., Floris C., Leonti M., Gertsch J., Heilmann J., 2005. New cytotoxic prenylated isoflavonoids from Bituminaria morisiana. Planta Med. 71, 254-260.

Djouossi M.G., Foning Tebou P.L., Mabou F.D., Ngnokam D., Tapondjou A.L., Harakat D. and Voutquenne-Nazabadioko L. 2014. Chevalierinoside A: a new isoflavonoid glycoside from the stem bark of Antidesma chevalieri Beille (Euphorbiaceae). Bull. Chem. Soc. Ethiopia 28, 1-6.

Farag S.F., Ahmed A.S., Terashima K., Takaya Y., Niwa M., 2001. Isoflavonoid glycosides from Dalbergia sissoo. Phytochemistry 57, 1263-1268.

Fedoreyev S.A., Bulgakov V.P., Grishchenko O.V., Veselova M.V., Krisvoschekova O.E., Kulesh N.I., Denisenko V.A., Tchernoded G.A., Zhuravlev Y.N., 2008. Isoflavonoid composition of a callus culture of the relict tree Maackia amurensis Rupr. et Maxim. J. Agric. Food Chem. 56, 7023-7031.

Harper A., Kerr D.J., Gescher A., Chipman J.K., 1999. Antioxidant effects of isoflavonoids and lignans, and protection against DNA oxidation. Free Radi. Res. 31, 149-160.

Komiyama K., Funayama S., Anraku Y., Mita A., Takahashi Y., Omura S., Shimasaki H., 1989. Isolation of isoflavonoids possessing antioxidant activity from the fermentation broth of Streptomyces sp. J. Antibiot. (Tokyo) 42, 1344-1349.

Kraft C., Jenett-Siems K., Siems K., Gupta M. P., Bienzle U., Eich E., 2000. Antiplasmodial activity of isoflavones from Andira inermis. J. Ethnopharmacolo. 73, 131-135.

Laupattarakasem P., Houghton P.J., Hoult J.R., 2004. Anti-inflammatory isoflavonoids from the stems of Derris scandens. Planta Med. 70, 496-501.

Macias, F.A., Simonet, A.M., Galindo, J.C.G., Pacheco, P.C. and Sanchez, J.A., 1998. Bioactive polar triterpenoids from Melilotus messanensis. Phytochemistry 49, 709-717.

Mackova Z., Koblovska R., Lapcik O., 2006. Distribution of isoflavonoids in non-leguminous taxa an update. Phytochemistry 67, 849-855.

Mayer, R., 1996. Three Lupane Derivatives from Leptospermum scoparium. Arch. Pharm. Pharm. Med. Chem. 329, 447-450. 
Nkengfack A.E., Azebaze A.G., Waffo A.K., Fomum Z.T., Meyer M., Van Heerden F.R., 2001. Cytotoxic isoflavones from Erythrina indica. Phytochemistry 58, 1113-1120.

Rahman A.U., Nasim S., Baig I., Jalil S., Orhan I., Sener B., Choudhary M.I., 2003. Antiinflammatory isoflavonoids from the rhizomes of Iris germanica. J. Ethnopharmacolo. 86, 177-180. Redko F., Clavin M. L., Weber D., Ranea F., Anke T., Martino V., 2007. Antimicrobial Isoflavonoids from Erythrina crista galli Infected with Phomopsis sp. Z. Naturforsch. 62c, 164-168.

Sato M., Tanaka H., Fujiwara S., Hirata M., Yamaguchi R., Etoh H., Tokuda C., 2003. Antibacterial property of isoflavonoids isolated from Erythrina variegata against cariogenic oral bacteria. Phytomedicine 10, 427-433.

Schmelzer G.H., 2008. Antidesma laciniatum Mull. Arg. In: Schmelzer, G. H., Gurib-Fakim, A. (Ed.). Ressources végétales de l'Afrique tropicale 11(1). Plantes Médicinales 1. Fondation PROTA, Wageningen, Pays-Bas/Backhuys Publishers, Leiden, Pays-Bas/CTA, Wageningen, Pays-Bas; 113115.

Shahat A.A., Nazif N.M., Abdel- Azim N.S., Pieters L., Vlietinck A.J., 2005. Flavonoids from Cressa cretica. Quatar Univ. Sci. J. 25, 72-77.

Sholichin M., Yamasaki, K., Kasai, R., Tanaka, O., 1980. ${ }^{13}$ C- Nuclear magnetic resonance of lupane type triterpenes. Lupeol, betulin and betulinic acid. Chem. Pharm. Bull. 28, 1006-1008.

Tang Y., Yang R., Duan J.A., Shang E., Su S., Zhu M., Qian D., 2008. Isoflavone tetraglycosides from Sophora japonica Leaves. J. Nat. Prod. 71, 448-450.

Veitch N.C., 2007. Isoflavonoids of the Leguminosae. Nat. Prod. Rep. 24, 417-464.

Wang J., Yang X., Di Y., Wang Y., Shen Y., Hao X., 2006. Isoflavone diglycosides from Glycosmis pentaphylla. J. Nat. Prod. 69, 778-782.

Yao-Kouassi P.A., Magid A.A., Richard B., Martinez A., Jacquier M.J., Caron C., Debar Ele M., Gangloff S.C., Coffy A.A., Zèches-Hanrot M., 2008. Isoflavonoid glycosides from the roots of Baphia bancoensis. J. Nat. Prod. 71, 2073-2076. 
Yenesew A., Derese S., Irungu B., Midiwo J.O., Waters N.C., Liyala P., Akala H., Heydenreich M., Peter M.G., 2003. Flavonoids and isoflavonoids with antiplasmodial activities from the root bark of Erythrina abyssinica. Planta Med. 69, 658-661.

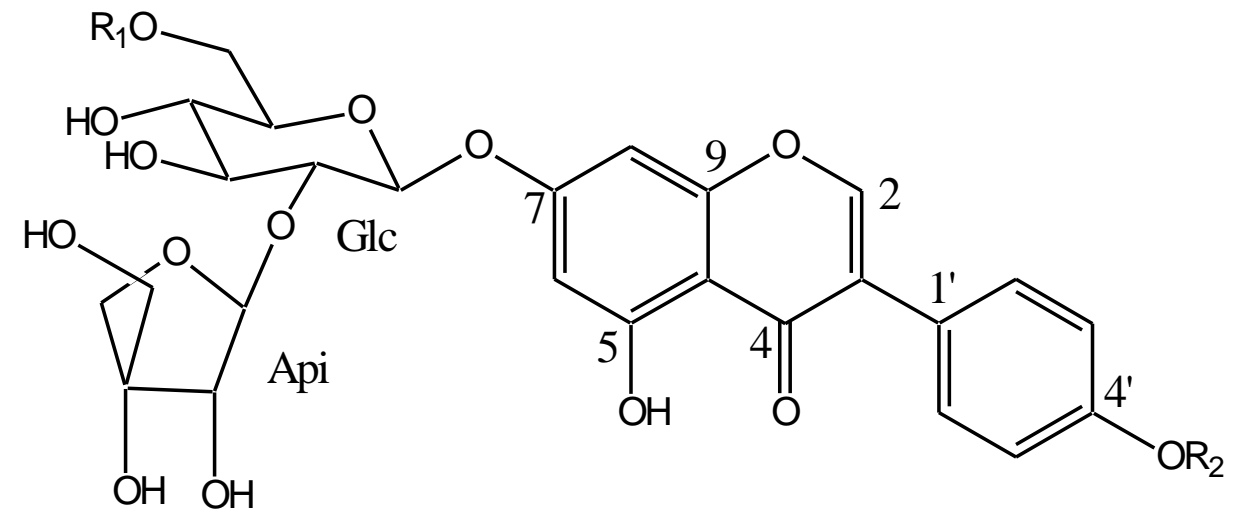

$$
\begin{array}{ll}
\mathbf{1} & \mathrm{R}_{1}=\mathrm{H} ; \mathrm{R}_{2}=\mathrm{Me} \\
\boldsymbol{2} & \mathrm{R}_{1}=\mathrm{H} ; \mathrm{R}_{2}=\mathrm{H} \\
\mathbf{3} & \mathrm{R}_{1}=\mathrm{Rha} ; \mathrm{R}_{2}=\mathrm{Me}
\end{array}
$$

Fig. 1. Chemical structure of compounds 1-3. 
Table 1: ${ }^{1} \mathrm{H}(600 \mathrm{MHz})$ and ${ }^{13} \mathrm{C}(150 \mathrm{MHz})$ NMR data of compounds $\mathbf{1}$ and $\mathbf{2}$ in $\mathrm{CD}_{3} \mathrm{OD}$, and some HMBC correlations of $\mathbf{1}$ and $\mathbf{2}$.

\begin{tabular}{|c|c|c|c|c|c|}
\hline \multirow[t]{2}{*}{ No } & \multicolumn{2}{|l|}{1} & \multicolumn{2}{|l|}{2} & \multirow[t]{2}{*}{ HMBC $(\mathrm{H} \rightarrow \mathrm{C})$} \\
\hline & $\delta \mathbf{C}$ & $\delta_{H}(m u l t ; J)$ & $\delta \mathrm{C}$ & $\delta_{\mathrm{H}}(\mathrm{mult} ; J)$ & \\
\hline 2 & 154.1 & $8.20(\mathrm{~s})$ & 153.9 & $8.17(\mathrm{~s})$ & $2,4,9,1^{\prime}$ \\
\hline 3 & 123.1 & & 123.7 & & \\
\hline 4 & 181.1 & & 181.8 & & \\
\hline 5 & 162.0 & & 162.2 & & \\
\hline 6 & 99.6 & $6.52(\mathrm{~d}, 2.3)$ & 99.5 & $6.52(\mathrm{~d}, 2.2)$ & $5,7,8,10$ \\
\hline 7 & 163.3 & & 163.2 & & \\
\hline 8 & 94.4 & $6.71(\mathrm{~d}, 2.3)$ & 94.4 & $6.71(\mathrm{~d}, 2.2)$ & $6,7,9,10$ \\
\hline 9 & 157.9 & & 157.9 & & \\
\hline 10 & 107.0 & & 106.6 & & \\
\hline $1^{\prime}$ & 122.9 & & 121.9 & & \\
\hline $2^{\prime}$ & 130.0 & $7.52(\mathrm{~d}, 8.9)$ & 130.0 & $7.42(\mathrm{~d}, 8.8)$ & $2,4^{\prime}$ \\
\hline $3^{\prime}$ & 113.5 & $7.02(\mathrm{~d}, 8.9)$ & 114.9 & $6.88(\mathrm{~d}, 8.8)$ & $1^{\prime}, 4^{\prime}$ \\
\hline $4^{\prime}$ & 159.7 & & 157.5 & & \\
\hline $5^{\prime}$ & 113.5 & $7.02(\mathrm{~d}, 8.9)$ & 114.9 & $6.88(\mathrm{~d}, 8.8)$ & $1^{\prime}, 4^{\prime}$ \\
\hline $6^{\prime}$ & 130.0 & $7.52(\mathrm{~d}, 8.9)$ & 130.0 & $7.42(\mathrm{~d}, 8.8)$ & $2,4^{\prime}$ \\
\hline $4^{\prime}-\mathrm{OMe}$ & 54.3 & $3.86(\mathrm{~s})$ & & - & \\
\hline \multicolumn{6}{|l|}{ Glc } \\
\hline 1 & 98.8 & $5.16(\mathrm{~d}, 7.5)$ & & $5.16(\mathrm{~d}, 7.5)$ & 7 \\
\hline 2 & 77.3 & $3.70(\mathrm{dd}, 8.8,7.5)$ & & $3.69(\mathrm{dd}, 9.2,7.5)$ & Glc-1, Api-1 \\
\hline 3 & 77.0 & $3.65(\mathrm{t}, 8.8)$ & & $3.65(\mathrm{t}, 9.2)$ & Glc-2, Glc-4 \\
\hline 4 & 69.8 & $3.43(\mathrm{dd}, 9.6,8.8)$ & & $3.43(\mathrm{t}, 9.3)$ & Glc-5 \\
\hline 5 & 76.9 & $3.52(\mathrm{~m})$ & & $3.53(\mathrm{~m})$ & \\
\hline \multirow[t]{2}{*}{6} & 61.0 & $3.73(\mathrm{dd}, 12.3,5.9)$ & & $3.73(\mathrm{dd}, 12.2,5.8)$ & \\
\hline & & $3.92(\mathrm{dd}, 12.3,2.2)$ & & $3.92(\mathrm{dd}, 12.2,2.2)$ & \\
\hline \multicolumn{6}{|l|}{ Api } \\
\hline 1 & 109.5 & $5.48(\mathrm{~d}, 1.7)$ & 109.5 & $5.47(\mathrm{~d}, 1.7)$ & Api-3, Api-4, Glc-2 \\
\hline 2 & 76.7 & $3.97(\mathrm{~d}, 1.7)$ & 76.7 & $3.97(\mathrm{~d}, 1.7)$ & Api-5 \\
\hline 3 & 79.3 & & 79.3 & & \\
\hline \multirow[t]{2}{*}{4} & 74.0 & $3.83(\mathrm{~d}, 9.6)$ & 74.0 & $3.83(\mathrm{~d}, 9.6)$ & Api-1, Api-2, Api-3, \\
\hline & & $4.04 \mathrm{~d}(9.6)$ & & $4.04(\mathrm{~d}, 9.6)$ & Api5 \\
\hline 5 & 64.4 & $3.56 \mathrm{~s})$ & 64.4 & $3.55(\mathrm{~s})$ & Api-2, Api-3, Api4 \\
\hline
\end{tabular}

